\title{
Evidence of Genomic Damage Induced By Prodigiosin Produced By Serratia Marcenscens Ufpeda 395 in Human Peripheral Blood Mononuclear Cells
}

\author{
Lapenda JCL*1, Adam ML ${ }^{2}$, Melo $\mathrm{MEB}^{3}$ and Nascimento $\mathrm{SC}^{4}$ \\ ${ }^{1}$ Department of Antibiotics, Postgraduate Program in Biological Sciences, Brazil \\ ${ }^{2}$ Department of Biological Sciences, Brazil
}

${ }^{3}$ Department of Parasilogy, Mutagenese Laboratorie, Brazil

${ }^{4}$ Department of Antibiotics, Brazil

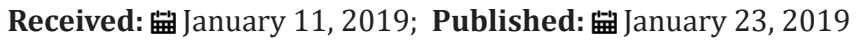

*Corresponding author: Lapenda JCL, Department of Antibiotics, Postgraduate Program in Biological Sciences, Brazil

\begin{abstract}
Prodigiosin is a natural red pigment belonging to the family of prodiginines that has demonstrated different biological activities. The aim of the present study was to investigate possible genomic damage caused by prodigiosin in normal human mononuclear cells. Prodigiosin extracted from $S$. marcescens was purified by column chromatography and characterized by gas chromatography-mass spectrometry, which determined a molecular mass of 323.4. Cell samples were acquired from human peripheral blood and cultivated in RPMI 1640 medium with phytohemagglutinin for 48 hours. The samples were exposed to different concentrations of prodigiosin $(0.5,1.0,10.0$ and $100.0 \mu \mathrm{M} / \mathrm{mL})$. Micronucleated cells were found after exposure to the of prodigiosin, with a statistically significant genotoxic effect in all treatments.

Apoptotic cells were also found in the concentrations of $100 \mu \mathrm{M} / \mathrm{mL}$. The Kruskal-Wallis test revealed statistically significant differences in comparison to the negative control regarding the frequency of micronucleated cells among all concentrations of prodigiosin, whereas significant differences were found in comparison to the positive control, except at concentrations of 0.5 . The comet assay revealed statistically significant differences from the negative control regarding genomic damage at concentrations of prodigiosin. No significant differences were found regarding the frequency of micronucleated cells or genomic damage in the comparison of cells from males and females. In conclusion, prodigiosin exhibited genotoxic effects, as evidenced by genomic damage in human mononuclear cells. Further studies are needed to clarify the target-specific mechanisms of action of prodigiosin, as the administration of this pigment in antitumor therapy poses the risk of genotoxicity to normal cells.
\end{abstract}

Keywords: Serratia Marcescens; Prodigiosin; Genotoxicity; Micronucleus

\section{Introduction}

Prodigiosin is synthesized by a number of microorganisms, such as Serratia marcescens. This compound represents the newest family of antitumor drugs and causes immunosuppression as well as the selective blocking of T lymphocytes, B lymphocytes and natural killer cells Montaner et al. [1,2]. Prodigiosin is a red pigment from the alkaloid class with a linear-chain tripyrrole structure (pyrrole, 3 methoxypyrrole, 2-methyl-3-amylpyrrole) Guryanov et al. [3] Like a number of secondary bacterial metabolites, prodigiosin has acquired practical importance in recent years. Beyond its pharmaceutical applications, this pigment has been employed industrially for dying methacrylate products, polymethylene and paper Mapari et al. [4-7] and has also been used in diverse methods for the acquisition of petroleum-based products Silva et al.
Prodigiosin is known to induce apoptosis in a variety of human cancer cells, with little toxicity to normal cells. This characteristic gives prodigiosin a huge advantage as an anti-cancer agent Pandey et al. $[8,9]$. The induction of DNA cleavage is among the mechanisms of action attributed to this compound Pérez-Tomás et al. [9]. Due to the growing use of prodigiosin as a pharmaceutical product (SigmaAldrich, CAS Number, 56144-17-3) and accumulating knowledge on its action as a potential anti-cancer agent Hsieh et al. [10], studies are needed to clarify its likely mechanisms of action to determine the best forms of administration. This need is based on the few data available on the selective action of prodigiosin in normal cells with regard to genomic damage. The aim of the present study was 
to investigate possible genomic damage induced by prodigiosin in normal human mononuclear cells through genotoxicity tests.

\section{Material and Methods}

\section{Acquisition of Prodigiosin}

Prodigiosin was obtained from the cultivation of Serratia marcescens UFPEDA 398. The pigment was purified using thinlayer chromatography, identified by UV-visible spectrometry in the 200 to $700 \mathrm{~nm}$ range and characterized using gas chromatographymass spectrometry based on the methods described by Nakashima et al. [11].

\section{Sample Collection}

Lymphocytes were obtained from human peripheral blood. The sample size was calculated based on 10 healthy individuals ( 5 men and 5 women between 20 and 50 years of age). The exclusion criteria for the participants were drug use, medication use, cardiovascular disease, cancer, hypertension and other adverse health conditions. This study received approval from the Human Research Ethics Committee of the Center for Health Sciences of the Federal University of Pernambuco (Brazil) under process number: 18177413.4.0000.5208. Approximately $5 \mathrm{~mL}$ of peripheral venous blood were collected from each individual using a sterile heparinized syringe for use in all treatments. The samples were duly labeled for subsequent processing Neves.

\section{Sample Processing}

After blood collection, the syringes were left in the vertical position for two hours to allow the sedimentation of the cells. Three layers were formed due to density differentiation: two layers of cells and a layer of plasma. For the isolation of the cells, the plasma from each sample was discarded and $1 \mathrm{~mL}$ of the cell layer containing lymphocytes (layer with a milky appearance) was transferred to a 5mL test tube containing RPMI 1640 medium (Cultilab) with phytohemagglutinine. The cells were then incubated for 48 hours at $37^{\circ} \mathrm{C}$ Mooreheat et al. [12]. For the comet assay, approximately $15 \mu \mathrm{l}$ of cell suspension were homogenized in $100 \mu \mathrm{l}$ of low-meltingpoint agar. After incubation, $1 \mathrm{~mL}$ of prodigiosin was added to the cultures at different concentrations $(0.5,1.0,10$ and $100 \mu \mathrm{M} / \mathrm{mL})$ and the samples were incubated for an additional 24 hours at $37{ }^{\circ} \mathrm{C}$.

The positive and negative controls were doxorubicin (at the same concentrations as prodigiosin) and the culture medium without the addition of any agents, respectively. Following incubation, the samples were transferred to centrifuge tubes and submitted to centrifugation at $1500 \mathrm{rpm}$ for 6 minutes. The culture medium was then discarded and the cells were re-suspended in $1 \mathrm{~mL}$ of phosphate buffered saline $\left(\mathrm{P}^{\mathrm{H}} 7.4\right)$. Two drops of cell suspension were transferred to previously washed, wet slides. The slides were left to dry in horizontal position at room temperature and then fixed with absolute methanol (P.A.) for 5 minutes. After rinsing in running water, the slides were stained with Giemsa stain (Merck), which was deposited uniformly and left to react for 5 minutes. The slides were once again rinsed in running water and left to dry at room temperature. The comet assay was used for the evaluation of genomic damage, following the method described by Singh et al. [13].

Approximately $15 \mu \mathrm{L}$ of cell suspension were homogenized in $100 \mu \mathrm{L}$ of low-melting-point agar previously heated to $37^{\circ} \mathrm{C}$ in a water bath. The homogenate was then transferred to glass slides coated with standard agarose, covered with cover slips and incubated for $10 \mathrm{~min}$ at $4^{\circ} \mathrm{C}$. The cover slips were removed and the slides were immersed in a lysis solution for two hours at $4^{\circ} \mathrm{C}$, followed by electrophoresis $(40 \mathrm{~V}$ for 20 minutes and 300 $\mathrm{mA}$ ). The slides were then immersed in a neutralization solution for 15 minutes and fixed with an absolute ethanol solution for 5 minutes. After drying, the slides were stored under refrigeration until staining. For such, Gel Red (Biotarget GelRed () ) (1 $\mu \mathrm{L})$ was homogenized in $1000 \mu \mathrm{L}$ of sterile de-ionized water (1:1000). After staining, the slides were analyzed with fluorescence microscopy (Olympus, BX Series) for the determination of the cell counts. According to Tice et al. [13], approximately 100 cells per individual were analyzed, with nucleoid damage scored from 0 (no damage, intact nucleus and missing comet tail), 1 (damage inicial, little nuclear fragmentation and small comet tail formation), 2 (moderate nuclear fragmentation and observation of comet tail formation), 3 (intense nuclear fragmentation, small nucleus materials preseverd and observation of a comet tail and prolonged) and 4 (intense nuclear fragmentation, almost no nuclear materials preserved and observation of a comet tail and prolonged).

\section{Data Analysis}

Micronucleated cells were analyzed under an optical microscope (Olympus BX 60) with an immersion objective. Approximately 1000 cells per individual were analyzed for the quantification of micronucleated cells. Cells with one or more micronuclei were included in the analysis. Bartlett's test of equal variance was used in the comparison of the samples. ANOVA was used for the comparison of samples with equal variance and the Kruskal-Wallis test was used for samples with unequal variance. Tukey's post hoc test was used for the confirmation of the results. The same tests were used in the comparison of cells from male and female individuals. The level of significance set to $5 \%(p<0.05)$ for all statistical tests.

\section{Results}

The formation of micronuclei occurred following exposure to the different concentrations of prodigiosin (Table 1) and (Figure 1). The pigment exhibited statistically significant genotoxic effects in all treatments (Figure 2). A direct relationship was found between the frequency of micronuclei and concentration of prodigiosin, with the largest mean number of micronuclei (62.6) found following exposure to the highest concentration of the pigment $(100 \mu \mathrm{M} / \mathrm{mL})$ (Table 1). This proportional increase in comparison to the negative control was evidenced with both prodigiosin and doxorubicin, with relative constancy found in the proportionality among the concentrations of these two substances (Table 2). Apoptotic cells were also found with the highest concentration of prodigiosina $(100 \mu \mathrm{M} / \mathrm{mL})$ (Figure 3) but were not quantified in the present study. 


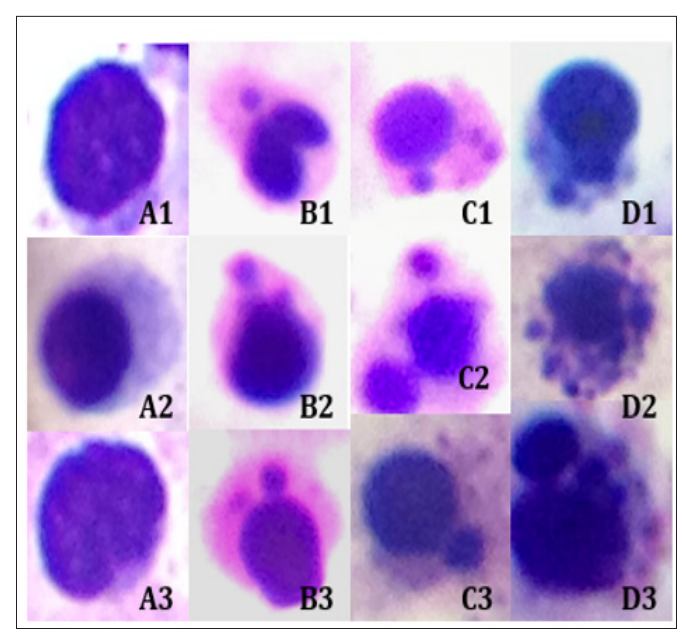

Figure 1: Presence of micronuclei in lymphocytes from human peripheral blood after 24 hours of exposure to different concentrations of prodigiosin; A1-A3: negative control (cells without micronuclei); B1-B3: micronuclei in cells exposed to 0.5 .

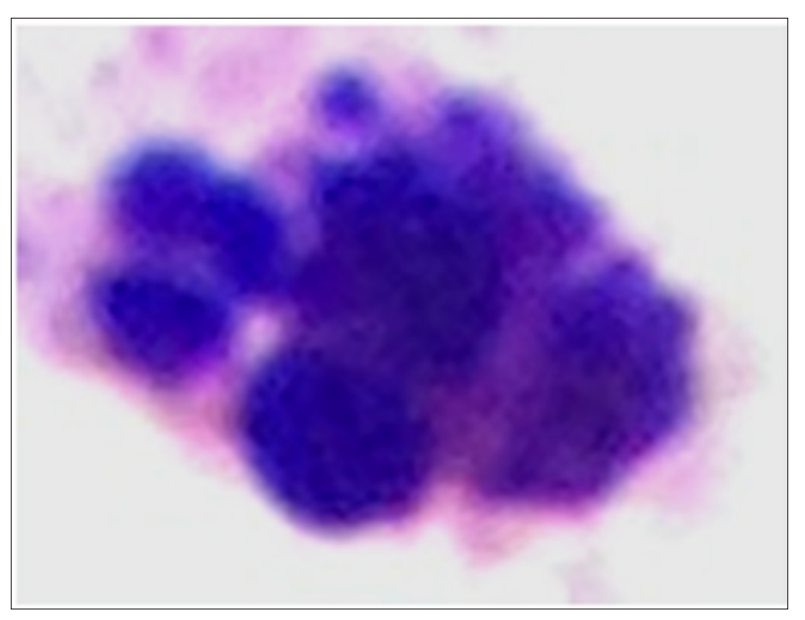

Figure 2: Apoptotic lymphocyte after 24 hours of exposure at concentration of $100 \mu \mathrm{M} / \mathrm{mL}$.

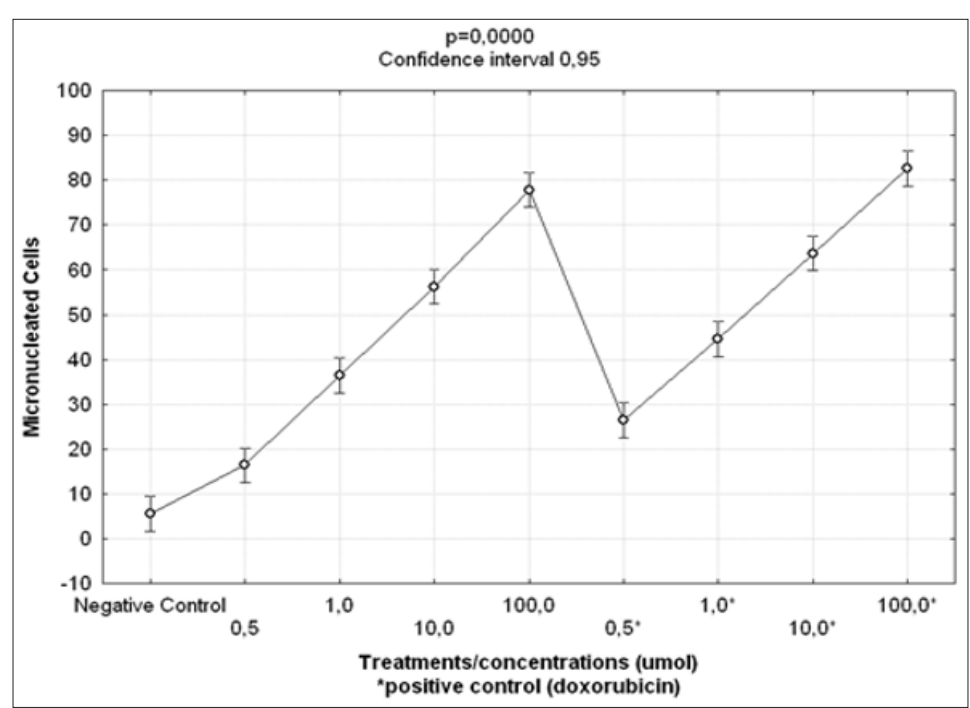

Figure 3: Results of Kruskal-Wallis test for comparisons of frequencies of micro nucleated cells following exposure to different concentrations of prodigiosin and doxorubicin. 
Table 1: Absolute and mean number of micronucleated cells following exposure to different concentrations of $(\mu \mathrm{M} / \mathrm{mL})$ of prodigiosin and doxorubicin.

\begin{tabular}{|c|c|c|c|c|c|c|c|c|c|}
\hline \multirow{3}{*}{ Individual/sex } & \multicolumn{9}{|c|}{ Treatment } \\
\hline & \multicolumn{4}{|c|}{ Prodigiosin } & \multicolumn{5}{|c|}{ Doxorubicin* } \\
\hline & $\begin{array}{c}\text { Control } \\
(-)\end{array}$ & 0.5 & 1.0 & 10.0 & 100.0 & 0.5 & 1.0 & 10.0 & 100.0 \\
\hline $1 \%$ & 3 & 12 & 28 & 40 & 68 & 16 & 30 & 52 & 75 \\
\hline $2 \%$ & 4 & 13 & 25 & 37 & 61 & 17 & 30 & 46 & 70 \\
\hline $3 \&$ & 2 & 8 & 15 & 24 & 52 & 10 & 18 & 30 & 62 \\
\hline $4 \%$ & 5 & 12 & 29 & 47 & 73 & 16 & 31 & 58 & 77 \\
\hline $5 \%$ & 2 & 10 & 21 & 35 & 55 & 14 & 28 & 44 & 62 \\
\hline $6 \odot$ & 2 & 8 & 17 & 29 & 48 & 12 & 22 & 36 & 58 \\
\hline $7 \odot$ & 0 & 6 & 21 & 43 & 70 & 17 & 26 & 47 & 73 \\
\hline 8 ఠ & 1 & 8 & 13 & 32 & 69 & 15 & 22 & 38 & 71 \\
\hline 9 क् & 3 & 12 & 26 & 39 & 77 & 18 & 29 & 45 & 80 \\
\hline 10 कా & 2 & 11 & 20 & 36 & 53 & 16 & 26 & 43 & 66 \\
\hline Mean & 2.4 & 10.0 & 21.5 & 36.2 & 62.6 & 15.1 & 26.2 & 43.9 & 69.4 \\
\hline
\end{tabular}

Note: *Positive control.

Table 2: Proportionality index of mean number of micronucleated cells in different treatments.

\begin{tabular}{|c|c|c|c|c|c|c|c|c|c|}
\hline \multicolumn{10}{|c|}{ Treatment } \\
\hline \multirow[b]{2}{*}{ Control } & \multicolumn{5}{|c|}{ Prodigiosin* } & \multicolumn{4}{|c|}{ Doxorubicin** } \\
\hline & Control & 0.5 & 1.0 & 10.0 & 100.0 & 0.5 & 1.0 & 10.0 & 100.0 \\
\hline & & 4.16 & 8.95 & 15.08 & 26.08 & 6.29 & 10.91 & 18.29 & 28.91 \\
\hline & & & 1.81 & 3.27 & 4.81 & 1.45 & & & \\
\hline & & & & 1.8 & 2.65 & & 1.3 & & \\
\hline & & & & & 1.47 & & & 1.19 & \\
\hline & & & & & & & & & 1.24 \\
\hline
\end{tabular}

Note: ** Positive control.

The Kruskal-Wallis test revealed statistically significant differences in comparison to the negative control regarding the frequency of micronucleated cells following exposure to the different concentrations of the substances. No significant differences were found between prodigiosin and the positive control, except at the concentration of $0.5 \mu \mathrm{M} / \mathrm{mL}$ (Figure 3). These findings were confirmed by Tukey's post hoc test (Table 3). The comet assay revealed statistically significant differences in comparison to the negative control regarding genomic damage at prodigiosin concentrations of 1.0, 10.0 and $100.0 \mu \mathrm{M} / \mathrm{mL}$ (Table 4) and (Figure 4). The ANOVA findings were confirmed by Tukey's post hoc test (Table 5). No significant differences were found regarding the frequency of micronucleated cells or genomic damage in the comparison of cells from males and females (Figures 5-7) and (Table 6).

Table 3: Results of Tukey's post hoc test for the comparison of frequencies of micronucleated cells following exposure to different concentrations $(\mu \mathrm{M} / \mathrm{mL})$ of prodigiosin and doxorubicin.

\begin{tabular}{|c|c|c|c|c|c|c|c|c|c|}
\hline \multirow{2}{*}{ Treatment } & \multicolumn{5}{|c|}{ Prodigiosin* } & \multicolumn{3}{c|}{ Doxorubicin** (+ Control) } \\
\cline { 2 - 9 } & Control (-) & $\mathbf{0 . 5}$ & $\mathbf{1 . 0}$ & $\mathbf{1 0 . 0}$ & $\mathbf{1 0 0 . 0}$ & $\mathbf{0 . 5}$ & $\mathbf{1 . 0}$ & $\mathbf{1 0 . 0}$ & $\mathbf{1 0 0 . 0}$ \\
\hline Control (-) & & 0.005428 & 0.000132 & 0.000132 & 0.000132 & 0.000132 & 0.000132 & 0.000132 & 0.000132 \\
\hline $0.5^{*}$ & 0.005428 & & 0.000132 & 0.000132 & 0.000132 & 0.013612 & 0.000132 & 0.000132 & 0.000132 \\
\hline $1.0^{*}$ & 0.000132 & 0.000132 & & 0.000132 & 0.000132 & 0.013612 & 0.100639 & 0.000132 & 0.000132 \\
\hline $10.0^{*}$ & 0.000132 & 0.000132 & 0.000132 & & 0.000132 & 0.000132 & 0.001860 & 0.172111 & 0.000132 \\
\hline $100.0^{*}$ & 0.000132 & 0.000132 & 0.000132 & 0.000132 & & 0.000132 & 0.000132 & 0.000190 & 0.721786 \\
\hline $0.5^{* *}$ & 0.000132 & 0.013612 & 0.013612 & 0.000132 & 0.000132 & & 0.000132 & 0.000132 & 0.000132 \\
\hline $1.0^{* *}$ & 0.000132 & 0.000132 & 0.100639 & 0.001860 & 0.000132 & 0.000132 & & 0.000132 & 0.000132 \\
\hline $10.0^{* *}$ & 0.000132 & 0.000132 & 0.000132 & 0.172111 & 0.000190 & 0.000132 & 0.000132 & & 0.000132 \\
\hline $100.0^{*}$ & 0.000132 & 0.000132 & 0.000132 & 0.000132 & 0.721786 & 0.000132 & 0.000132 & 0.000132 & \\
\hline
\end{tabular}

Cite this article: Lapenda JCL, Adam ML, Melo MEB, Nascimento SC. Evidence of Genomic Damage Induced By Prodigiosin Produced By Serratia Marcenscens Ufpeda 395 in Human Peripheral Blood Mononuclear Cells. Biomed J Sci \& Tech Res 13(3)-2019. BJSTR. MS.ID.002414. DOI: 10.26717/ BJSTR.2019.13.002414. 
Note: Non-significant values in bold type.

Statistical significance: $\mathrm{p}<0.05$.

Table 4: Damage indices following exposure to different concentrations $(\mu \mathrm{M} / \mathrm{mL})$ of prodigiosin.

\begin{tabular}{|c|c|c|c|c|c|}
\hline \multirow{2}{*}{ Individual/sex } & \multicolumn{5}{|c|}{ Treatment } \\
\hline & Control (-) & 0.5 & 1.0 & 10.0 & 100.0 \\
\hline $1 \%$ & 1.19 & 1.28 & 1.38 & 1.46 & 1.77 \\
\hline $2 \&$ & 1.38 & 1.42 & 1.57 & 1.51 & 1.88 \\
\hline $3 \&$ & 1.20 & 1.31 & 1.30 & 1.50 & 1.65 \\
\hline $4 \%$ & 1.64 & 1.70 & 1.53 & 1.43 & 1.55 \\
\hline $5 \%$ & 1.50 & 1.57 & 1.70 & 1.74 & 1.75 \\
\hline 6 fr $^{\circ}$ & 1.0 & 1.53 & 1.46 & 1.53 & 1.60 \\
\hline 7 कా & 1.36 & 1.74 & 1.59 & 1.66 & 1.68 \\
\hline $8 \odot$ & 1.53 & 1.61 & 1.61 & 1.75 & 1.81 \\
\hline 9 कా & 1.14 & 1.20 & 1.48 & 1.57 & 1.65 \\
\hline 10 क् & 1.14 & 1.71 & 1.73 & 1.70 & 1.81 \\
\hline
\end{tabular}

Table 5: Results of Tukey's post hoc test in comparison of damage indices following exposure to different concentrations $(\mu \mathrm{M} / \mathrm{mL})$ of prodigiosin.

\begin{tabular}{|c|c|c|c|c|c|}
\hline Treatment & Control (-) & $\mathbf{0 . 5}$ & $\mathbf{1 . 0}$ & $\mathbf{1 0 . 0}$ & $\mathbf{1 0 0 . 0}$ \\
\hline Control (-) & & $\mathbf{0 . 0 5 1 0 5 1}$ & $\mathbf{0 . 0 1 8 6 6 6}$ & $\mathbf{0 . 0 0 2 5 7 9}$ & $\mathbf{0 . 0 0 0 1 3 8}$ \\
\hline 0.5 & & & 0.994540 & 0.800133 & 0.037345 \\
\hline 1.0 & 0.051051 & & 0.952748 & 0.094928 \\
\hline 10.0 & 0.018666 & 0.994540 & & 0.358197 \\
\hline 100.0 & 0.000138 & 0.037345 & 0.094928 & 0.358197 & \\
\hline
\end{tabular}

Note: Non-significant values in bold type.

Table 6: Results of Tukey's post hoc test for the comparison between sexes regarding frequencies of micronucleated cells and damage indices following exposure to different concentrations $(\mu \mathrm{M} / \mathrm{mL})$ of prodigiosin.

\begin{tabular}{|c|c|c|c|c|}
\hline \multirow{2}{*}{ Sex } & \multicolumn{3}{|c|}{ Methodological Approaches } \\
\cline { 2 - 4 } & \multicolumn{2}{|c|}{ Micronucleated cells } & \multicolumn{2}{|c|}{ Damage index } \\
\hline Female & Female & Male & Female & Male \\
\hline Male & 0.952301 & & & 0.637392 \\
\hline
\end{tabular}

Note: Non-significant values in bold type.

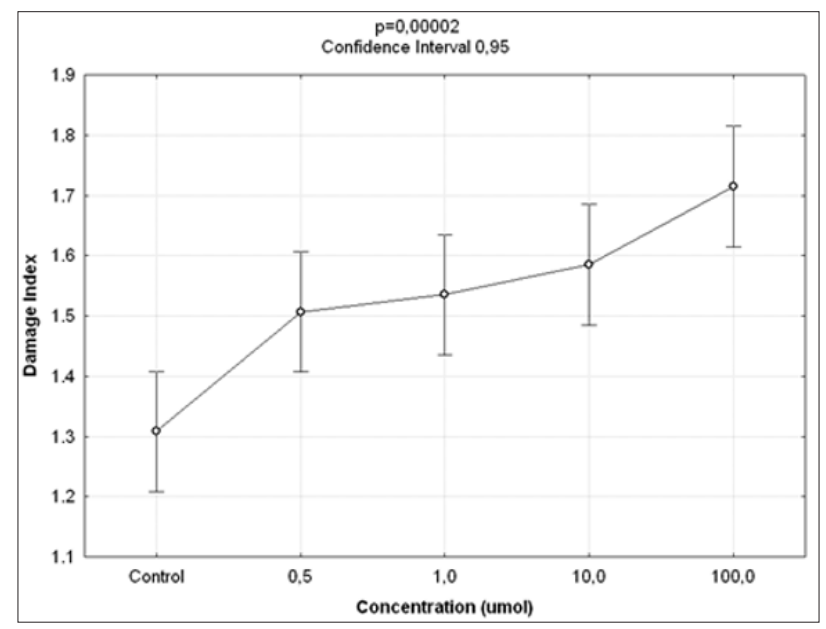

Figure 4: Results of ANOVA in comparison of damage indices in lymphocytes following exposure to different concentrations of prodigiosin. 


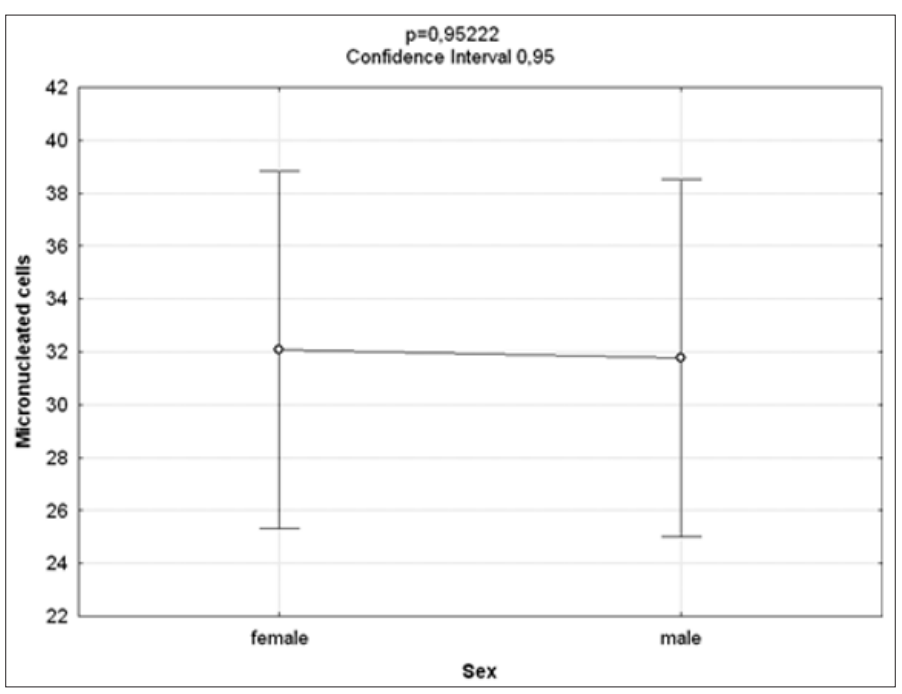

Figure 5: Results of ANOVA for comparisons between sexes of frequencies of micro nucleated cells following exposure to different concentrations of prodigiosin.

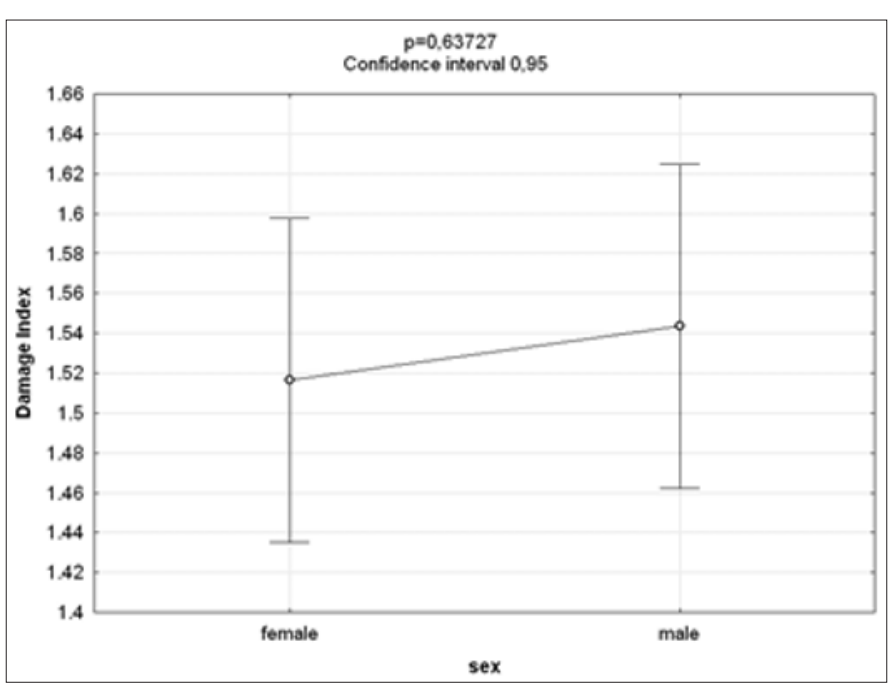

Figure 6: Results of ANOVA for comparisons between sexes of damage to lymphocytes following exposure to different concentrations of prodigiosin.
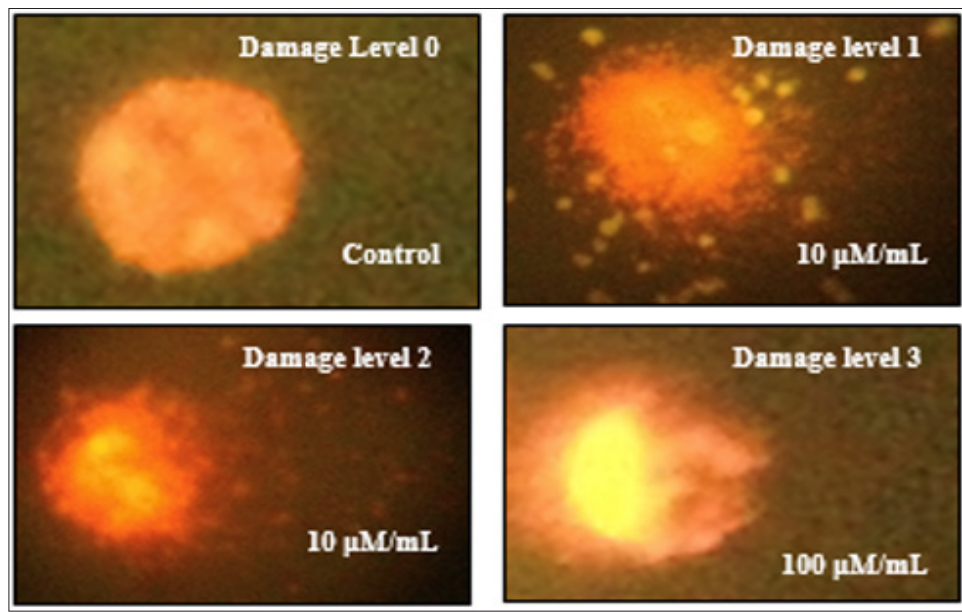

Figure 7: Genomic damage observed in normal human peripheral mononuclear blood cells after treatment with different concentrations of prodigiosin $(0.5,1.0,10.0$ and $100.0 \mathrm{mM} / \mathrm{ml})$ of $48 \mathrm{~h}$. 


\section{Discussion}

Prodigiosin is considered a promising anti-cancer agent due to its mechanisms of action and selective toxicity, affecting only cancer cells Pérez-Tomáz et al. [14-16]. However, the present findings indicate a considerable effect on normal cells, as evidenced by the high number of micronucleated cells and significant damage index (comet assay) at all concentrations tested on normal lymphocytes. The genotoxic effect of prodigiosin demonstrated a dose-dependent relationship, as a greater frequency of micronucleated cells occurred at the highest concentrations tested (Table 1), regardless of the sex of the volunteers from which the cells were taken (Table 6) and (Figures 5 \& 6). This relationship was also demonstrated by the proportionality indices (Table 2). The expression of micronuclei was fourfold greater at the lowest concentration of prodigiosin tested $(0.5 \mu \mathrm{M} / \mathrm{mL})$ and 26 -fold greater at the highest concentration $(100.0 \mu \mathrm{M} / \mathrm{mL})$. It was observed that the prodigiosin induced genomic damage in cells from the lower concentration $0.5 \mu \mathrm{M} / \mathrm{mL}$ whereas this concentration increases obviously observed a more intense level of damage. Therefore, it can be stated concentrations equal or above $10 \mu \mathrm{M} / \mathrm{mL}$ induce significant damage grade 2 and 3 (Figure 7).

Both prodigiosin and the positive control (doxorubicin) demonstrated considerable genomic damage to the lymphocytes, with doxorubicin exhibiting a greater effect in comparison to prodigiosin when the drugs were used at a concentration of $0.5 \mu \mathrm{M} /$ $\mathrm{mL}$, as evidenced by the results of Tukey's post hoc test (Table 3) and the mean values displayed in (Table 1). The similarity in the dose-dependent effect of these drugs is likely due to their structural similarity. Both prodigiosin and doxorubicin are DNA intercalating agents. Due to their planar chemical structure, these molecules are capable of interacting with the DNA molecule and affecting its stability Montaner et al. [14]. Four mechanisms are considered regarding the action of prodigiosin as an anti-cancer agent:

a. The induction of intracellular acidification;

b. The induction of DNA cleavage through the inhibition of topoisomerase I and II;

c. The modulation of MAPK activity; and

d. The inhibition of the progression of the cell cycle PerezTomás et al. [9-10].

Among these mechanisms of action, the first three can lead to the induction of apoptosis Soto Cerrato et al. [17]. Regarding the mechanism related to DNA cleavage, Montaner et al. [15] report that the binding of prodigiosin to the double strand inhibits the action of topoisomerase I and II, transforming these essential enzymes into lethal DNA-damaging agents (Turner and Denny, 1996; Montaner et al. $[18-19,15]$. Prodigiosin fixes enzyme-DNA cleavage complexes, resulting in breaks in the DNA molecule Montaner et al. [15]. These DNA fragments may give rise to micronuclei during cell division, as suggested by the findings of the present study (Figure 1). This fragmentation can also been seen in the significant differences in the damage indices among the different concentrations of prodigiosin tested in relation to the negative control (Tables 4 \& 5)
(Figure 4). Damage to the double strand of DNA as a consequence of the inhibition of topoisomerase by prodigiosin is dependent on the processing of chromatin related to the apoptotic process induced by the drug Campás et al. $[1,15,9]$. This independent relationship of the two effects of prodigiosin was evidenced in the present study. Apoptotic cells (Figure 2) were only found following exposure to $100.0 \mu \mathrm{M} / \mathrm{mL}$ of the pigment, whereas genomic damage was found after exposure to all concentrations tested (Tables $1 \& 4$ ). The presence of apoptotic cells at the highest concentration is in partial agreement with data reported by Soto Cerrato et al. [17], who found that low, non-cytotoxic concentrations of prodigiosin cause blocking of the cell cycle and high concentrations induce apoptosis. (The suppression of the cell cycle was not evaluated in the present study.) Moreover, the genomic damage found at all concentrations likely stems from the induction of oxidative damage to DNA by prodigiosin Melvin et al. [20,21] .

Few data have been published on the genotoxic effects of prodigiosin, especially on normal cells, which underscores the biotechnological innovation of the present investigation. Larazo et al. [22] found no significant mutagenic or genotoxic effects of prodigiosin with regard to micronucleus counts in Salmonella typhimuriun or L51718y lymphocytes obtained from lymphomas in rats using the Ames test. Guryanov et al. [3] also found no significant genotoxic effects of this pigment on Salmonella typhimuriun and peripheral red blood cells from mice. However, it describes the mutagenic potential of prodigiosin evidenced by Ames test. In contrast, Cavalcanti et al. [23], states that prodigiosin induces toxic effect decreasing cell viability when treated at lower concentrations of 0.6 to $4.8 \mu \mathrm{M} / \mathrm{mL}$ as the highestthe. These data corroborate those found in present study substantial genotoxic effects on normal lymphocytes, as both evaluation methods employed demonstrated significant clastogenicity. As prodigiosin can cause breaks in both DNA strands and such damage is more difficult for the cell to repair Montaner et al. [15], cells submitted to this drug can become compromised due to the induction of apoptosis and the harmful effects of genomic damage.

The therapeutic potential of prodigiosin in the treatment of cancer is widely recognized in the medical-scientific community, mainly due to its direct action on DNA, leading to the suppression of the cell cycle and apoptosis of cancer cells Hsieh et al. [10,16]. However, the genotoxic effects found in the present study suggest non-selective action, with effects on normal cells as well. Therefore, further studies on the effects of this drug should be carried out on different normal cells lines for the confirmation of the non-selective genotoxic effects of prodigiosin to ensure greater efficiency and the minimization of risks regarding the use of this drug.

\section{Conclusion}

Prodigiosin exhibited significant genotoxic effects on normal human lymphocytes exposed to different concentrations of this pigment for 24 hours. These effects were evidenced by an increase in the frequency of micronuclei and genomic damage to the cells analyzed. 


\section{Acknowledgment}

The authors are grateful to the technical team for their assistance, the Federal University of Pernambuco and Departamento of Parasitology, Mutagenese Laboratorie, Center Aggeu MagalhãesFIOCRUZ-PE for the use of the laboratories and the Brazilian fostering agencies CNPq and CAPES.

\section{References}

1. Campás C, Dalmau M, Montaner B, Barragán M, Bellosillo B, et al. (2003) Prodigiosin induces apoptosis of $\mathrm{B}$ and $\mathrm{T}$ cells from B-cell chronic lymphocytic leukemia. Leukemia 17(4): 746-750.

2. Pandey R, Chander R, Sainis KB (2003) A novel prodigiosin -like immunosuppressant from an alkalophilic Micrococcussp Int Immunopharmacol 3: 159-167.

3. Guryanov ID, Karamova NS, Yusupova OI, Gnezdilov, Koshkaranova LA (2013) Bacterial Pigment Prodigiosin and its Genotoxic Effect. Russian Journal of Bioorganic Chemistry 39(1): 121-128.

4. Mapari SAS, Nielsen KF, Larsen TO, Frisvad JC, Meyer AS, et al. (2005) Exploring fungal biodiversity for the production of water-soluble pigments as potential natural food colorants. Curr Opin Biotechnol 16(2): 109-238.

5. Tibor C (2007) Liquid chromatography of natural pigments and synthetic dyes. ( $1^{\text {st }}$ edn.), J Chromatogr Lib 71: 1-602.

6. Jissa GK, Soorej MB, Elyas KK, Chandrasekaran M (2011) Prodigiosin from marine bacterium: Production, Characterization and Application as dye in textile industry. Int J Biotechnol Biochem 7(1): 155-191.

7. Krishna JG, Jacob A, Kurian P, Elyas KK, Chandrasekaran M (2013) Marine bacterial prodígios in as dye for rubber latex, polymethyl methacrylate sheets and paper. African Journal of Biotechnology 12(17): 2266 -2269.

8. Pandey R, Chander R, Sainis KB (2009) Prodigiosins as anti-cancer agents: living upto their name. Curr Pharm Des 15(7): 732-741.

9. Pérez Tomás R, Viñas M (2010) New insights on the antitumoral properties of prodiginines. Curr Med Chem 17(21): 2222-2231.

10. Hsieh HY, Shieh JJ, Chen CJ, Pan MY, Yang SY, et al. (2012) Prodigiosin down-regulates SKP2 to induce p27KIP1 stabilization and antiproliferation in human lung adenocarcinoma cells. British Journal of Pharmacology 166(7): 2095-2108.

11. Nakashima T, Myiazaki Y, Matsuyam Y, Muraoka W, Yamaguchi K, et al. (2006) Producing mechanism of an algicidal compound against red tide phytoplankton in a marine bacterium $\gamma$-proteobacterium. App Microbiol Biotechnol 73(3): 684-690.

\section{ISSN: 2574-1241}

DOI: 10.26717/BJSTR.2019.13.002414

Lapenda JCL. Biomed J Sci \& Tech Res

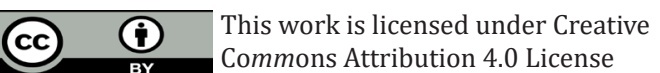

Submission Link: https://biomedres.us/submit-manuscript.php
12. Moorhead PS, Nowell PC, Mellman WJ, Battips DM, Hungerford DA (1969) Chromosome preparation of leucocytes cultured from human peripheral blood. Exp Cell Res 20(3): 613-615.

13. Singh NP, Mc Coy MT, Tice RR, Schneider EL (1988) A simple technique for the quantification of low levels of DNA damage in individual cells. Exp Cell Res 175(1): 184-191.

14. Pérez Tomáz, Montaner B, Llagostera E, Soto Cerrato V (2003) The prodigiosins, proapoptotic drugs with anticancer properties. Biochemical pharmacology 66(8): 1447-1452.

15. Montaner B, Castillo Ávilla W, Martinell M, Ollinger R, Ayamami J, et al. (2005) DNA Interaction and Tpoisomerase I and II Inhibition Properties of the Anti-Tumor Drug Prodigiosin. Toxicological Sciences 85(2): 870879.

16. Lu CH, Lin SC, Yang SY, Pan MY, Lin YW, et al. (2012) Prodigiosin-induced cytotoxicity involves RAD51 down-regulation through the JNK and p38 MAPK pathways in human breast carcinoma cell lines. Toxicology Letters 212: 83-89.

17. Soto Cerato V, Viñals F, Lambert JR, Kelly JA, Perez Tomas R (2007) Prodigiosin induces the proapoptotic gene NAG-1 via glycogen synthase kinase-3beta activity in human breast cancer cells. Mol Cancer Ther 6(1): 362-369.

18. Palchaudhuri R, Hergenrother PJ (2007) DNA as a target for anticancer compounds: methods to determine the mode of binding and the mechanism of action. Current opinion in biotechnology 18(6): 497-503.

19. Ho TF, Peng YT, Chuang SM, Lin SC, Feng BL, et al. (2009) Prodigiosin down-regulates survivin to facilitate paclitaxel sensitization in human breast carcinoma cell lines. Toxicology and Applied Pharmacology 235(2): 253- 256.

20. Melvin MS, John T Tomlinson, Gilda R Saluta, Gregory L Kucera, Neils Lindquist, et al. (2000) Double-strand DNA cleavage by copper prodigiosin. Journal of the American Chemical Society 122(26): 63336334.

21. Montaner B, Perez Tomas R (2001) Prodigiosin-induced apoptosis in human colon cancer cells. Life Sci 68(17): 2025-2036.

22. Lazaro JE, Nitcheu J, Predicala RZ, Mangalindan GC, Nesslany F, et al. (2002) Heptyl prodigiosin, a bacterial metabolite, is antimalarial in vivo and non-mutagenic in vitro. J Nat Toxins 11(4): 367-377.

23. Cavalcanti BC, Júnior HV, Seleghim MH, Berlinck RG, Cunha G, et al. (2008) Cytotoxic and genotoxic effects of tambjamine D, an alkaloid isolated from the nudibranchi Tambja eliorai, on Chinese hamster lung fibroblasts. Chemico Biological interactions 174(3): 155-162.

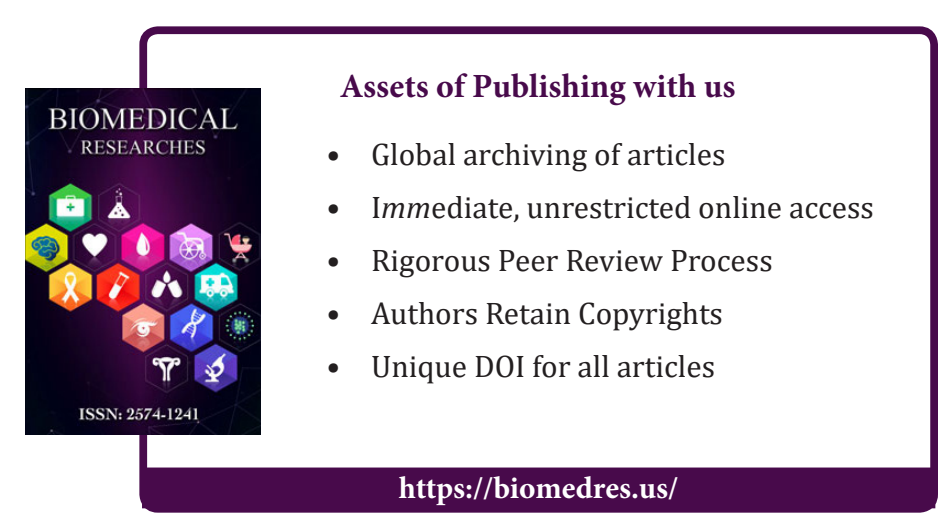

Cite this article: Lapenda JCL, Adam ML, Melo MEB, Nascimento SC. Evidence of Genomic Damage Induced By Prodigiosin Produced By Serratia Marcenscens Ufpeda 395 in Human Peripheral Blood Mononuclear Cells. Biomed J Sci \& Tech Res 13(3)-2019. BJSTR. MS.ID.002414. DOI: 10.26717/ BJSTR.2019.13.002414. 